\title{
Relative chlorophyll index of maize and soybean according to weather conditions at different times of day
}

\author{
Luciana Maria da Silva ${ }^{1}$, Lucas Robson Oliveira ${ }^{1}$, Fabrício Rodrigues ${ }^{1}$, Katiane Santiago \\ Silva Benett ${ }^{1}$, Cleiton Gredson Sabin Benett ${ }^{1}$
}

\author{
${ }^{1}$ Universidade Estadual de Goiás, Campus Ipameri, Ipameri, Goiás, Brasil. E-mail: luy.mari@ hotmail.com, lucas- \\ florestal@outlook.com, fabricio.rodrigues@ueg.br, katiane.benett@gmail.com, cleiton.benett@gmail.com
}

Received: 19/05/2020; Accepted: 29/05/2020.

\section{ABSTRACT}

The present study aimed to identify the best day time to evaluate the relative chlorophyll index in maize and soybean crops as a function of weather conditions. The experiments were conducted in the 2018/2019 harvest, in January and February, in the experimental area of the State University of Goiás, Ipameri University Unit, in Ipameri-GO. A completely randomized design with three replications and 40 plants per plot was used. The measurements of relative chlorophyll index at 7:00, 10:00, 13:00, 16:00, and 19:00, at the maize stage R1 (silking) and soy stage R2 (full bloom), were evaluated. The replications consisted of alternating days over seven days. The relative chlorophyll index, leaf temperature, air temperature, and relative humidity, and light incidence were evaluated. The data were organized, and regression analysis was performed for all variables. The statistical analysis was processed using the Sisvar statistical analysis software. The maize shows higher values of relative chlorophyll index at times with the highest temperatures. For soybean, the relative chlorophyll index must be measured at temperatures close to $30{ }^{\circ} \mathrm{C}$. Studies with more species of $\mathrm{C}_{3}$ metabolisms, such as soybeans, should be carried out to standardize an adequate time to read the relative chlorophyll index.

Keywords: Zea mays L., Glycine max L., Portable chlorophyll meter, FCI.

\section{Índice relativo de clorofila nas culturas do milho e da soja em função das condições meteorológicas de diferentes horários}

\section{RESUMO}

O presente trabalho teve como objetivo identificar o melhor horário para a avaliação do índice relativo de clorofila nas culturas do milho e da soja em função das condições meteorológicas. Os experimentos foram conduzidos na safra de 2018/2019, nos meses de janeiro e fevereiro, na área experimental da Universidade Estadual de Goiás, Unidade Universitária de Ipameri, localizada no município de Ipameri-GO. Foram avaliados os horários 7:00, 10:00, 13:00, 16:00 e 19:00 horas (h), num delineamento inteiramente casualizado com três repetições e 40 plantas por parcela, no estádio de desenvolvimento $\mathrm{R}_{1}$ (pendoamento) do milho e no estádio $\mathrm{R}_{2}$ (florescimento pleno) da soja. As repetições foram os dias alternados num período de sete dias. Foram avaliados o índice relativo de clorofila, a temperatura da folha, a temperatura e umidade relativa do ar e a incidência de luz. Os dados foram tabulados e realizada a análise de regressão para todas variáveis. A análise estatística foi processada utilizando-se o programa de análise estatística Sisvar. A cultura do milho apresenta valores maiores de índice relativo de clorofila nos horários com maior temperatura. Para a cultura da soja, o índice relativo de clorofila deve ser mensurado em temperaturas próximas aos $30{ }^{\circ} \mathrm{C}$. Estudos com mais espécies de metabolismo $\mathrm{C}_{3}$, como a soja, devem ser realizados para se padronizar um horário mais adequado para se realizar a leitura do índice relativo de clorofila.

Palavras-chave: Zea mays L., Glycine max L., Clorofilômetro portátil, ICF. 
In Brazil, agricultural production has become fundamental for society and the economy, due to its importance in the composition of the gross domestic product (GDP) and because it is determinant for the food security of the population (Oliveira et al., 2018). The 2018/19 harvest showed an estimate of 241.3 million tons of grain, that is, around $6 \%$ or 13.7 million tons $(\mathrm{t})$ higher than the previous harvest. The crops that most increased the cultivation area were second-crop maize and soybeans, reaching 894 and 726.6 thousand cultivated hectares, respectively. In the Midwest region, the largest production of these crops is concentrated, in which the state of Goiás is responsible for the production of $8,156.4$ thousand tons of maize and 11,437.4 thousand tons of soybeans, where the planting area was increased $2.1 \%$ concerning the 2017/2018 harvest, reaching about $35,875.8$ thousand hectares (CONAB, 2019).

The improvement of scientific knowledge and different management technologies contribute to the growing production of grains, together with physiological studies, which allowed a better understanding of plant metabolism. Chlorophylls are among the main components of the plant physiology, which are closely associated with photosynthesis, acting in the photochemical phase, and converting light radiation into energy in the form of NADPH and ATP, with the release of oxygen $\left(\mathrm{O}_{2}\right)$. Because it is closely related to the development and productivity of plants, chlorophylls become an important parameter for assessing the physiological aspect (Taiz and Zeiger, 2013).

Traditionally, the content of chlorophylls in leaves is made by macerating the leaves in an organic solvent and later measuring in a spectrophotometer; however, this is a time-consuming method that destroys plant material (Arnon, 1949). Nowadays, easy-to-perform methods for an approximate determination of the leaf chlorophyll content are already available, in a non-destructive way, being carried out with the aid of portable meters that are based on the absorbance of light by the leaves (Naus et al., 2010).

These meters are the chlorophyll meters, which work via light transmittance through the leaf, and their measuring can be performed in two or three wavelengths, being: 635 for chlorophyll "b", 650 for chlorophyll "a" and $840 \mathrm{~nm}$, which acts to correct the degree of hydration and thickness of the leaf. The collected data are processed, and the results are shown on the equipment display, in the format of the indirect chlorophyll measure called SPAD or FCI.

Portable chlorophyll meters have been used to diagnose the nutritional status, growth and development of different crops, such as maize (Amarante et al., 2010; Nascimento et al., 2015), bean (Sant'ana, et al., 2010;
Anjos et al., 2017) and soy (Gomes et al., 2017; Yokoyama et al., 2018; Djanaguiraman et al., 2019; Coelho et al., 2019), because the chlorophyll present in the plants can serve as an indication of the nutritional status of the plant, mainly for nitrogenous bases. It is noteworthy that the amount of nitrogen in the plant varies with temperature, light, relative humidity conditions, and phenological stage, and these factors affect the indirect measure of chlorophyll (Godoy et al., 2010); however, there is no need for destruction of plant material for determination.

For wheat, Mamrutha et al. (2017) found that leaf characteristics, such as the movement of chloroplasts, are influenced by the change in irradiance over a day. In this way, the optical properties of the leaf may change over the day and, consequently, the relative chlorophyll index values. Silva et al. (2011), when evaluating the relative chlorophyll index at different day times and positions in the potato leaflet grown with different doses of nitrogen, observed that the evaluation times influence the results.

In this way, several studies present the results of the relative chlorophyll index without presenting the period or the day time when the information was collected. Most studies with relative chlorophyll index are performed to evaluate the influence of a given product on the crop physiological process, mainly on nitrogen fertilization. Given the above, the present study aimed to identify the best day time to evaluate the relative chlorophyll index in maize and soybean crops as a function of weather conditions.

The experiments were carried out in the 2018/2019 harvest, in January and February, in the experimental area of the State University of Goiás, Ipameri University Unit, in Ipameri-GO (17\%42'40" S;

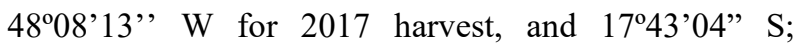
$48^{\circ} 07^{\prime} 55^{\prime}$ ' W for 2018 harvest, with an average altitude of $759 \mathrm{~m}$ ). The climate of the region, according to the Köppen-Geiger classification (Cardoso et al., 2014), is Aw type, tropical with a dry season in winter. The climatic data during the months of conduction of the research are shown in Figure 1.

The soil of the experimental area is classified as dystrophic Red-Yellow Latosol (EMBRAPA, 2018). The chemical and particle size characteristics of the soil were determined before the installation of the experiment. The soil had the following values of chemical and particle size attributes, in the $0.0-0.20 \mathrm{~cm}$ layer: P (Melich): $9.3 \mathrm{mg} \mathrm{dm}^{-3}$; O.M.: $17.1 \mathrm{~g} \mathrm{dm}^{-3}$; $\mathrm{pH}$ $(\mathrm{CaCl} 2): 6.20 ; \mathrm{K}: 0.26 \mathrm{cmol}_{\mathrm{c}} \mathrm{dm}^{-3} ; \mathrm{Ca}: 2.40 \mathrm{cmol}_{\mathrm{c}} \mathrm{dm}^{-3}$; Mg: $0.90 \mathrm{cmol}_{\mathrm{c}} \mathrm{dm}^{-3}, \mathrm{H}+\mathrm{Al}: 1.70 \mathrm{cmol}_{\mathrm{c}} \mathrm{dm}^{-3}$; base saturation: $67.7 \%$; clay: $475 \mathrm{~g} \mathrm{~kg}$; silt: $75 \mathrm{~g} \mathrm{~kg}$; and sand: $450 \mathrm{~g} \mathrm{~kg}$. 


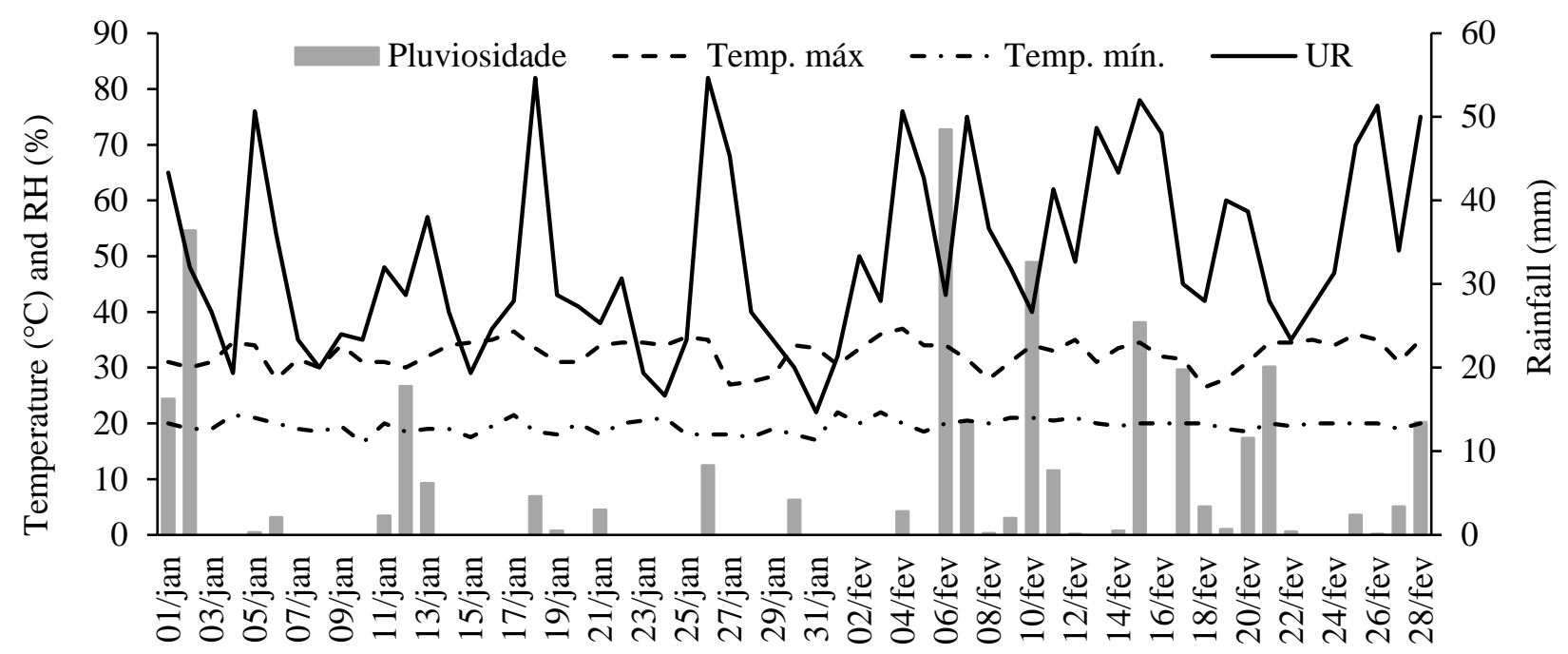

Evaluation dates

Figure 1. Maximum and minimum temperature, relative air humidity (RH), and rainfall ( $\mathrm{mm}$ ) accumulated between January and February 2019. Ipameri - GO, 2019.

A completely randomized design was used, with three replications and 40 plants per plot. The measurements of relative chlorophyll index at five times of day: 7:00, 10:00, 13:00, 16:00, and 19:00 were evaluated. The measurements were performed on alternate days for seven days. The data were organized, and the general average for these evaluations was obtained. As it is summer in the State of Goiás, the evaluations took place until 19:00.

Maize (Zea mays L.) and soybean (Glycine max L.) were evaluated according to the recommendation of Ribeiro et al. (1999) for leaf diagnosis. The maize crop was at the stage R1 (silking) and the soybean at the stage R2 (full bloom). The soybean cultivar M7110 IPRO and the maize hybrid LG 6030 were used, and, for both crops, was performed only the fertilization in the sowing furrow, as recommended for each crop.

The no-tillage system was used on maize straw for soybean cultivation, with a spacing of $0.45 \mathrm{~m}$ between rows and 15 plants per meter. The maize cultivation was performed on the vegetable remains of the sunflower crop, with spacing $0.50 \mathrm{~m}$ between lines and 3.3 plants per meter. The sowing of both crops was carried out with a pneumatic seeder with seven rows, equipped with a seed distribution mechanism with vertical discs and fertilizer distribution mechanisms with shanks.

The variables evaluated were: a) relative chlorophyll index: the reading was performed on 40 plants, in the central part of the crop field, with the aid of a portable chlorophyll meter (chlorofiLOG model CFL 1030), the values being expressed as Falker chlorophyll index (FCI). The leaves were identified on the first evaluation day, so that in the measurements at different day times throughout the week, the same leaves were evaluated, in the same order; b) leaf temperature: among the 40 plants used, eight leaves were identified to perform the reading with the aid of a digital infrared thermometer (model GM-300), with a distance of $10 \mathrm{~cm}$ from the leaf, in ${ }^{\circ} \mathrm{C}$; c) air temperature and relative humidity: they were collected at each evaluation time, being checked twice, at the beginning and the end of each evaluation, using a thermo-hygrometer (model SH-122), where the temperature was presented in ${ }^{\circ} \mathrm{C}$ and the relative humidity in \%; d) Incidence of light: the measuring was performed with the aid of a digital lux meter (LD-400), with the measuring taken twice, at the beginning and the end of the evaluation, and represented in Lux.

The data were organized, and regression analysis was performed for all variables. The statistical analysis was processed using the Sisvar statistical analysis software (Ferreira, 2014).

It is possible to observe, for the relative chlorophyll index and the leaf temperature, that the results showed significant adjustment $(\mathrm{p}<0.05)$ for both crops (Figures $2 \mathrm{~A}$ and $2 \mathrm{~B}$ ).

When evaluating the relative chlorophyll index for soybean and maize (Figure 2A), it was possible to observe the adjustment of the data to quadratic regression. When the maize was evaluated, it was observed that the highest relative chlorophyll index was 54.3 FCI estimated at 13:39. As for soybean, the highest index was 40.6 FCI estimated at 17:30.

The highest values of relative chlorophyll index for the maize were observed at times with the highest temperature (Figure 3A) and the highest incidence of light (Figure 3C), thus demonstrating that the evaluation times can influence the estimated relative chlorophyll index (Naus et al., 2010). Air temperature is influenced by several micrometeorological factors, especially by the solar irradiance, and plants that have a high 
chlorophyll content can achieve high photosynthetic rates according to the appropriate temperature for plant development (Porra et al., 1989).

Plants with $\mathrm{C}_{3}$ metabolism (soybean) reach their maximum photosynthesis rate before $\mathrm{C}_{4}$ plants (maize), however, when observing the average values for relative chlorophyll index in the present study, it was possible to observe that the values for maize crop were higher than those observed for soybean (Figure 2A). This fact is due to the high temperatures observed during the evaluation $\left(36.6{ }^{\circ} \mathrm{C}\right.$ ), as $\mathrm{C}_{3}$ metabolism plants have less $\mathrm{CO}_{2}$ assimilation at temperatures above $30{ }^{\circ} \mathrm{C}$, thus causing deleterious effects, such as the degradation of the chlorophyll molecule (Kerbauy, 2004).

Thus, it appears that the evaluation times of the relative chlorophyll index in the maize and soybean can influence the results obtained, and these are information of great importance for future studies with these species.

The temperature of the leaf in the maize was $34.4^{\circ} \mathrm{C}$, estimated at 14:00, and for the soybean, it was $32.3{ }^{\circ} \mathrm{C}$ estimated at 14:20 (Figure 2B). The air temperature and light incidence directly influence the leaf temperature, since, with the light, the synthesis of chlorophyll by the plant is stimulated and produces a greater amount of photoassimilates, which demonstrates a strong connection of the chlorophyll molecule with it weather element (Taiz and Zeiger, 2013).

During the evaluation of the maize, the highest temperature recorded was $37.1{ }^{\circ} \mathrm{C}$ at 15:00, and for the soybean, it was $36.7{ }^{\circ} \mathrm{C}$ estimated at 14:00 (Figure 3A). The lowest relative air humidity in the maize crop was $42.36 \%$ at $14: 00$, and in the soybean crop, it was $49.16 \%$ estimated at 13:39 (Figure 3B). The relative humidity of the air, when it varies throughout the day (Figure 3B) and because it is correlated and has an inverse temperature behavior (Figure 3A), directly influences the measurement and results of the relative chlorophyll index.

Chlorophyll values determined by SPAD and destructive analyzes (laboratory) are close and highly

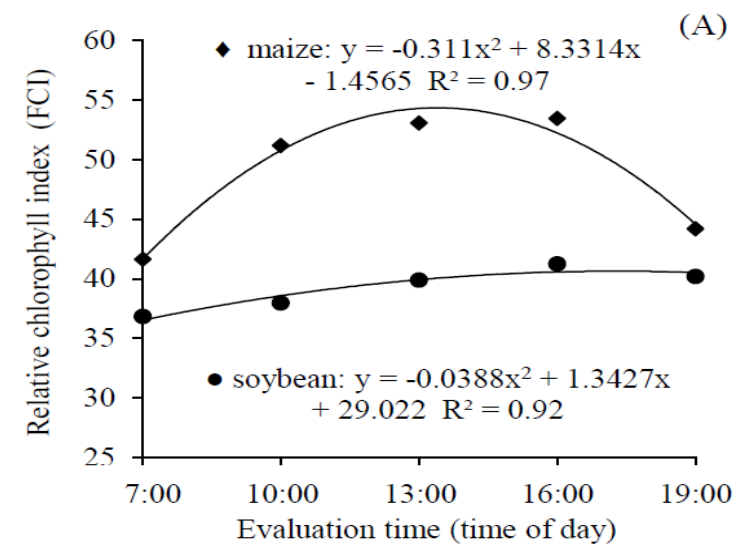

correlated, with little influence of relative air humidity, even in conditions of 65 to $95 \%$, and the greatest differences in values are obtained with the variation of nitrogen (Vesali et al., 2015). Studies of chlorophyll with cupuaçu (Theobroma grandiflorum Schum., Sterculiaceae), lemon (Citrus limon L., Rutaceae), annatto (Bixa orellana L., Bixaceae) e araçá-boi (Eugenia stipitata Mac Vaugh, Myrtaceae) in leaves with different degrees of greening in the dry and rainy seasons of Manaus-AM, showed that there is no correlation between the relative levels obtained by SPAD and by the laboratory, especially in well-green leaves with underestimation of SPAD values, which suggests a chlorophyll unevenness in the leaf surface and the need for instrument calibration in the measurement of each new species (Jesus and Marenco, 2008).

The highest light incidence on the maize crop was 124,315 Lux estimated at 13:10, and for the soybean, it was 114,095 Lux estimated at 13:28 (Figure 3C). It is observed that the highest light incidence was, on average, 40 minutes before the highest air temperature (Figure 3A), as it is necessary to heat and occur the emission of long waves (thermal) from the soil to heat the air. Besides promoting photosynthesis, the light incidence influences the growth of crops and the gain of dry matter, and, combined with temperature, affects the cycle of crops and the quality of harvested products (Boldt and Altland, 2019).

The highest light incidence (Figure 3C), promoting the highest air temperature (Figure 3A) and, consequently, the lowest relative air humidity (Figure $3 \mathrm{~B}$ ), directly influences the leaf temperature (Figure 2B), as well as, the relative chlorophyll index (Figure $2 \mathrm{~A})$. For maize, the evaluation time of the relative chlorophyll index is directly related to the factors of air temperature, relative air humidity, and light incidence, influencing the maximum accumulation of chlorophyll molecules, and it is recommended to evaluate in times with the highest temperature and light incidence.

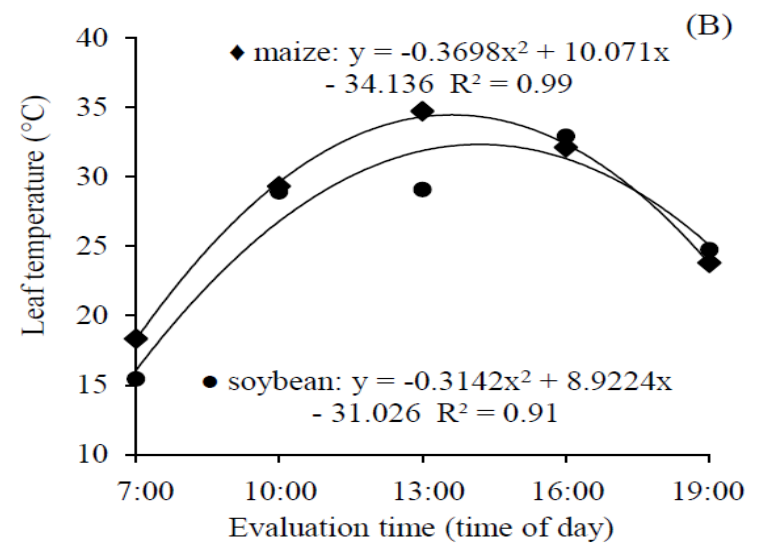

Figure 2. Relative chlorophyll index (A) and leaf temperature (B) of maize and soybean crops according to the evaluation at different times of day. Ipameri - GO, 2019. 

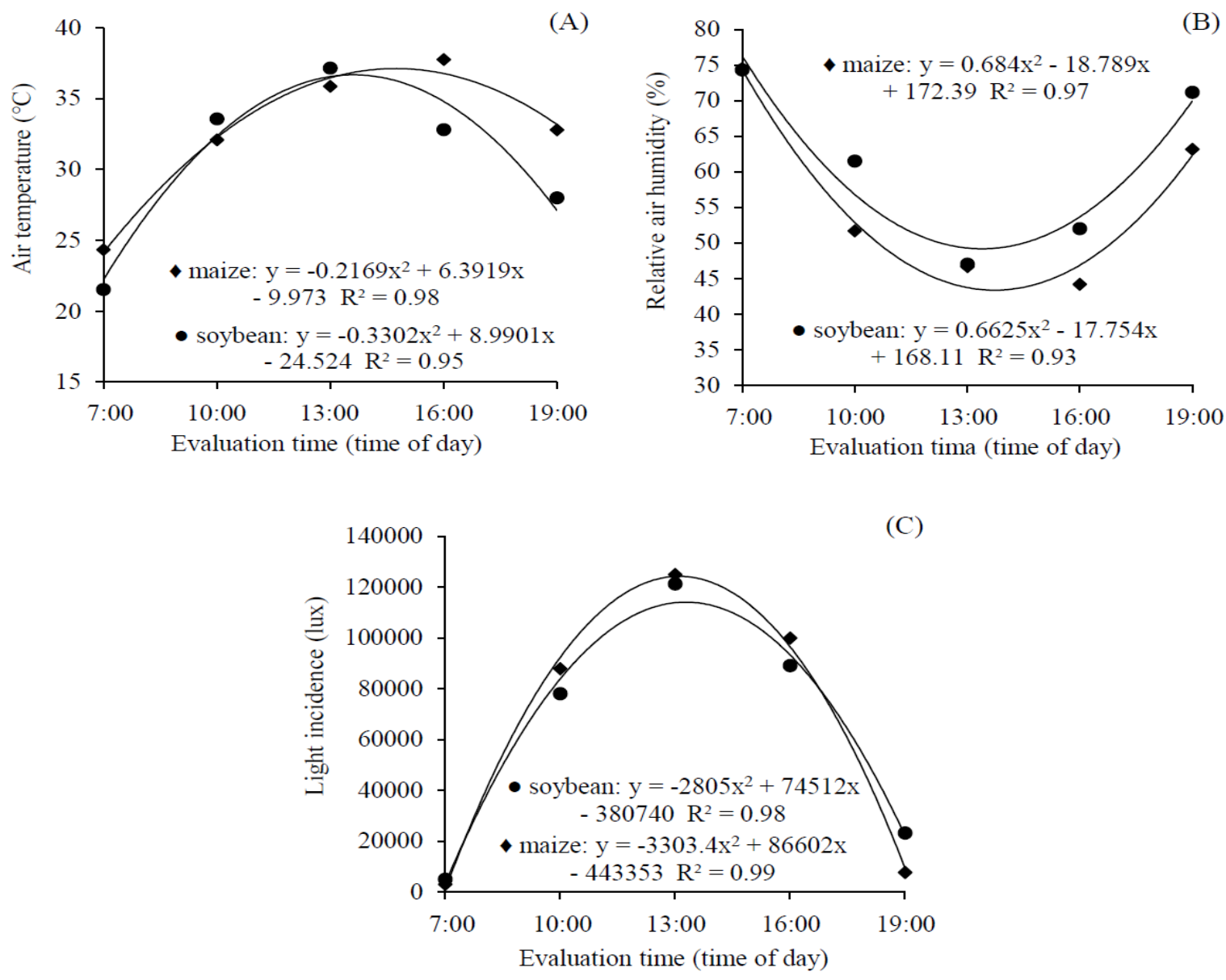

Figure 3. Air temperature (A), relative air humidity (B), and light incidence (C) according to the evaluation at different times of day in maize and soybean crops. Ipameri- GO, 2019. *significant at $5 \%$ probability.

For the soybean, the evaluations of the relative chlorophyll index must be carried out at temperatures up to $30{ }^{\circ} \mathrm{C}$, since they are plants with a $\mathrm{C}_{3}$ metabolism, which may suffer degradation of the chlorophyll molecules at higher temperatures, which can affect the result of the relative chlorophyll index. It is worth mentioning that further studies are needed to identify the influence of temperatures above $30{ }^{\circ} \mathrm{C}$ in the evaluation of the relative chlorophyll index in soybean and other $\mathrm{C}_{3}$ metabolism plants.

The maize has higher values of relative chlorophyll index at times with higher temperatures. For soybean, the relative chlorophyll index must be measured at air temperatures close to $30^{\circ} \mathrm{C}$.

Studies with more species of $\mathrm{C}_{3}$ metabolism, such as soybean, should be carried out to standardize an adequate time to measure the relative chlorophyll index.

\section{Acknowledgments}

The State University of Goiás, Ipameri University Unit (Universidade Estadual de Goiás, Unidade Universitária de Ipameri) for support in the installation and conduct of the project. To the Phytotechnics Study and Research Group (GEPFi).

\section{Bibliographic References}

Amarante, C.V.T., Steffens, C.A., Sangoi, L., Zanardi, O.Z., Miqueloto, A., Schweitzer, C., 2010. Quantificação de clorofilas em folhas de milho através de métodos ópticos não destrutivos. Revista Brasileira de Milho e Sorgo, 9(1), 39-50.

Anjos, D.N., Mendes, H.T.A., Vasconcelos, R.C., Moreira, P.M., Cangussu, A.C.V., Pires, E.S., 2017. Avaliação do feijoeiro comum em função dos bioestimulantes, NPK e micronutrientes em Vitória da Conquista - BA. Agrarian, 10(35), 1-9.

Arnon, D.I., 1949. Copper enzymes in isolated chloroplasts: polyphenoloxidases in Beta vulgaris. Plant Physiology, 24(1), $1-15$.

Boldt, J.K., Altland, J.E., 2019. Timing of a Short-Term Reduction in Temperature and Irradiance Affects Growth and Flowering of Four Annual Bedding Plants. Horticulturae, 5(1), 15 .

Coelho, P.H.M., Benett, K.S.S., Arruda, N., Benett, C.G.S., Nascimento, M.V., 2019. Crescimento e produtividade de dois cultivares de soja em função de doses de silício. Revista de Agricultura Neotropical, 6(3), 60-65.

CONAB. Companhia Nacional de Abastecimento, 2019. Ministério da Agricultura, Pecuária e Abastecimento. Acompanhamento da Safra Brasileira, Safra 2018/2019. Brasília, Ministério da Agricultura, Pecuária e Abastecimento, $65 \mathrm{p}$. 
Djanaguiraman, M., Schapaugh, W., Fritschi, F., Nguyen, H., Prasad, P.V., 2019. Reproductive success of soybean (Glycine $\max$ L. Merril) cultivars and exotic lines under high daytime temperature. Plant, Cell and Environment, 42(1), 321-336.

EMBRAPA. Empresa Brasileira de Pesquisa Agropecuária, 2018. Centro Nacional de Pesquisas de Solos. Sistema brasileiro de classificação dos solos, quinta ed. Brasília, Empresa Brasileira de Pesquisa Agropecuária, 586 p.

Ferreira, D.F., 2014. Sisvar: a Guide for its Bootstrap procedures in multiple comparisons. Ciência e Agrotecnologia, 38(2), 109-112.

Godoy, L.J.G., Souza, T.R, Villas Bôas, R.L., 2010. Perspectivas de uso de métodos diagnósticos alternativos: Análise da seiva e medida indireta da clorofila, in: Prado, R.M., Cecílio Filho, A.B., Correa, M.A.R., Puga, A.P., (Eds.). Nutrição de plantas: diagnose foliar em hortaliças. Fundunesp, Jaboticabal, p. 135-184.

Gomes, I.S., Benett, C.G.S., Silva Junior, R.L., Xavier, R.C., Benett, K.S.S., Silva, A.R., Coneglian, A., 2017. Boron fertilisation at different phenological stages of soybean. Australian Journal of Crop Science, 11(8), 1026-1032.

Jesus, S.V.D., Marenco, R.A., 2008. O SPAD-502 como alternativa para a determinação dos teores de clorofila em espécies frutíferas. Acta Amazonica, 38(4), 815-818.

Kerbauy, G.B., 2004. Fisiologia Vegetal. Guanabara Koogan, Rio de Janeiro.

Mamrutha, H.M., Sharma, D., Sumanth Kumar, K., Venkatesh, K., Tiwari, V., Sharma, I., 2017. Influence of diurnal irradiance variation on chlorophyll values in wheat: A comparative study using different chlorophyll meters. National Academy Science Letters, 40(3), 221-224.

Nascimento, F.N., Bastos, E.A., Cardoso, M.J., Júnior, A.S.A., Ribeiro, V.Q., 2015. Parâmetros fisiológicos e produtividade de espigas verdes de milho sob diferentes lâminas de irrigação. Revista Brasileira de Milho e Sorgo, 14(2), 167-181.
Naus, J., Prokopovs, J., Rebicek, J., Spundova, M., 2010 SPAD chlorophyll meter reading can be pronouncedly affected by chloroplast movement. Photosynthesis Research, 105(3), 265-271.

Oliveira, T.A.S., Oliveira Neto, O.J., Silva, E.A., 2018 Influência de variáveis socioeconômicas na produção brasileira de grãos. Desafio Online, 6(3), 570-597.

Porra, R.J., Thompson, W.A., Kriedemann, P.E., 1989. Determination of accurate extinction coefficients and simultaneous equations for assaying chlorophylls $\mathrm{a}$ and $\mathrm{b}$ extracted with four different solvents: verification of the concentration of chlorophyll standards by atomic absorption spectroscopy. Biochimica et Biophysica Acta (BBA) Bioenergetics, 975(3), 384-394.

Ribeiro, A.C., Guimarães, P.T.G., Alvarez, V.H., 1999. Recomendações para o uso de corretivos e fertilizantes em Minas Gerais - $5^{\mathrm{a}}$ aproximação. UFV, Viçosa.

Sant'ana, E.V.P., Santos, A.B., Silveira, P.M., 2010. Adubação nitrogenada na produtividade, leitura Spad e teor de nitrogênio em folhas de feijoeiro. Pesquisa Agropecuária Tropical, 40(4), 491-496.

Silva, M.C.C., Coelho, F.S., Braun, H., Fontes, P.C.R., 2011. Índice SPAD em função de diferentes horários e posições no folíolo da batata sob fertilização nitrogenada. Revista Ciência Agronômica, 42(4), 971-977.

Taiz, L., Zeiger, E., 2013. Fisiologia vegetal, quinta ed. Artemed, Porto Alegre.

Vesali, F., Omid, M., Kaleita, A., Mobli, H., 2015. Development of an android app to estimate chlorophyll content of corn leaves based on contact imaging. Computers and Electronics in Agriculture, 116(1), 211-220.

Yokoyama, A.H., Balbinot, J., Zucareli, C., Ribeiro, R.H., 2018. Leaf area index and SPAD during the soybean development cycle at different plant densities and their relation to grain yield. Revista de Ciências Agroveterinárias, 17(4), 531-538. 